\title{
Psychological and Psychiatric Considerations in a Kidnapped- For-Ransom Victim: A Clinical Case Study
}

\author{
Akhigbe $\mathrm{KO}^{1} \&$ Koleoso $\mathrm{ON}^{2}$ \\ ${ }^{1,2}$ Department of Mental Health, University of Benin Teaching Hospital, Benin City, Nigeria
}

\begin{abstract}
Kidnapping has become one of the most dangerous and traumatic threats to any person living in the comfort and safety of a secure region. Each kidnapping incident clearly tears at the hearts of families, companies and individuals, and has a significant impact on society in general. The impact of such trauma and the capacity of individuals and companies to adapt, manage and cope with such devastating events are crucial if the risks of long-term effects are to be mitigated. Of significant note also is the emotional and financial effect of such on the individual and families if the incident is unresolved in the long term. This greatly disrupts the family routine, social interaction and the employment capabilities of some families. This study presents the psychological and psychiatric considerations in a kidnapped-for-ransom victim in one of the towns in Niger Delta region of Nigeria. Psychological assessment shows that the victim suffers both physical and psychological harm as a result of the negative experiences. The evaluation of psychological harm suffered by victims is important for planning treatment and giving recommendations to prevent revictimisation and avoiding the making of new victims.
\end{abstract}

Keywords: Kidnap, Psychological Harm, Nigeria, Ransom, Victim

\section{Introduction}

Kidnapping for ransom is a varied and developing phenomenon, but it is most common in countries with high levels of crime and corruption, poorly resourced or trained police personnel, a weak judiciary, and/or a history of political or social instability and conflict [1]. In these countries, kidnapping is often more profitable and less likely to lead to conviction than other generally high-yield crimes, like bank robbery. The growth of the phenomenon can be seen "as the logical outcome of [criminals] seeking new avenues to make quick profits from unlawful activities" $[1,2]$. Nigeria was ranked as the $6^{\text {th }}$ of the top 10 Kidnap Rated Countries in the world, coming after Mexico, Brazil, Colombia, Venezuela and Philippines[3] but by 2012, she has emerged as the $4^{\text {th }}$ of the Top Ten Kidnap for Ransom nations in the world.

Globally, the statistics are far more disturbing. British's Foreign Policy Centre estimates that kidnappers earn more than $\$ 500$ million annually, with the 2004 statistics indicating 8,000 - 10,000 investigators worldwide [4]. It is estimated that as many as $80 \%$ of all kidnappings for ransom occur in Latin America, but kidnapping appears to be a growing problem in sub-Saharan Africa, Eastern Europe, Central Asia, the Balkans and the Middle East [1,2]. Hargroves [5] (1994) avers that out of more than 15,000 reported kidnap cases each year, over seventy per cent are reported by ransom payments. Only an estimated ten per cent of those held to ransom are successfully rescued by the security forces. Fortunately, few kidnaps result in the death of the hostage. Kidnapping for ransom is not a new problem, but has become a growing business worldwide, to the extent that, in some countries (not yet in Nigeria) there are now numerous international insurance companies providing personal and corporate kidnapping insurance policies [6].

According to Zannoni [1], motivations and modus operandi vary, but generally there are two main kinds of kidnapping for ransom. These can be roughly categorised as "criminal kidnapping", where the main motive is to obtain a ransom from the family or business of the victim. This category includes instances where criminals take hostages as a shield to help them escape from the scene of a crime, or use them to obtain money or valuables, or the keys or secret codes needed to access areas where these are stored. Ralph [4] described a type of kidnapping, very similar to the cases in Nigeria, which he refers to as "tiger kidnapping". It involves the abduction or holding of a hostage with the intention of forcing an employee or his/her relative to facilitate the immediate theft of valuables or to concede some other form of ransom from an institution or business organisation. In this type of kidnapping, it is not necessarily the executives that are at risk, but those at middle and lower management positions targeted as victims or accomplices. The other type of kidnapping, according to Zannoni [1], is "political kidnapping", where the foremost objective is to further the political aims of a particular political group or movement. In this case, a ransom is usually demanded to obtain money for the group to fund their activities.For whichever type of kidnapping, the psychological and financial impact can be quite devastating, both for the victims and their significant others.

Petersen [7] claims that whether the motivation of the kidnappers are due to ideological, economic or personal reasons, kidnappings have similar effects on the victim and his or her family and company. For the 
victim, the experience is tormenting. Often cramped in appalling conditions, the captive may be open to the elements of health hazards, or subject to threats or beatings that can lead to injury and even death. Hargrove [5] asserts that the hostage remains at the mercy of kidnappers who are generally uninhibited killers, especially when confronted with the threat of armed force or when angered by poorly negotiated terms of release or the risk being identified by a victim. Only a balanced negotiation based on a detailed understanding of complexities of kidnapping for ransom offer the hostage his or her best chance of survival and freedom. Hargrove in his book, "Long march to freedom: the true story of a Colombian kidnapping" indeed described kidnapping as a "deliberate creation and marketing of human grief, anguish and despair" [5]. According to Petersen [7], throughout the incarceration, the victim's family is crippled by fear and uncertainty about the welfare of their loved one, who the kidnappers are, why they abducted their loved one and if the matter can, or will, be safely resolved. The word kidnap was first recorded in the cant or thieves dictionaries that became popular in the seventeenth and eighteenth centuries [8]. A kidnapper, according to Captain Grose's Dictionary of the Vulgar Tongue, was originally one who stole or decoyed children or apprentices from their parents or masters, to send them to the colonies [9].

Adibe [10] reported that kidnapping is becoming everyone's nightmare in Nigeria. Daily, we read frightening stories of people being abducted as they go about their daily business. A criminal act, which first attracted national attention on 26 February 2006 when Niger Delta militants kidnapped foreign oil workers to press home their demand, kidnapping has since become ever-present and commercialised. It has spread from the Niger Delta to virtually everywhere in Nigeria, with some states being hotspots. Similarly, victims have changed from being principally foreign oil workers to Nigerians, including parents, grandparents, and toddlers and about anyone who has a relative that could be blackmailed into coughing out a ransom. Those behind the recent wave of the despicable act have also changed from being exclusively Niger Delta militants to ruthless elements from different walks of life -armed robbers, unemployed, professional fraudsters, and at least one (religious0 priest. There is no doubt that Nigeria is today one of the major kidnapping capitals of the world [10].

Kidnapping for ransom is a violent crime. Violent crimes are negative events that usually happen suddenly, generating fear and helplessness, threaten people's physical or psychological well-being and leave victims in an emotional state which they are unable to deal with using their normal psychological resources [11]. Any kind of trauma - and a violent crime is a type of trauma for the victim - involves a collapse of the person's feelings of security, also affecting indirectly their immediate family circle. Apart from the suffering of the direct victim, the entire family structure is affected [12].

Psychological harm refers to the acute psychological damage resulting from a violent crime, and which, in some cases, may subside with the passage of time, with social support or with appropriate psychological treatment. It also refers to the emotional consequences that persist in a chronic fashion and interferes negatively with the person's everyday life. In either case, the psychological harm is the consequence of a negative event that produces a new situation with which the victim is unable to cope and to which he or she is incapable of adapting [13].

Psychological harm tends to pass through different phases. According to Echeburua et al. [12], in the first stage, there is usually a reaction of being overwhelmed with a clouding of awareness and general bewilderment, characterized by slowness, general dejection, disbelief and lack of ability to react appropriately. In the second phase, as awareness sharpens and the bewilderment produced by the state of shock dissipates, more dramatic emotional reactions appear: pain, indignation, anger, impotence, guilt, or fear, alternating with periods of profound dejection. Finally, there is a tendency for flashbacks, either spontaneously or as a stimulus specifically associated with it, or of a general stimulus, for example, a violent film, the anniversary of the kidnapping, to mention a few.

Psychological damage refers to an acute clinical alteration a person suffers as a consequence of having been a victim of kidnapping, and which significantly incapacitates him or her in relationship to everyday demands at a personal, work, family or social level [12]. Acierno, Kilpatrick and Resnick [14] describe the most common type of psychological damage to be adaptive disorders and the imbalance of an anomalous personality. They specifically note that, at a cognitive level, the victim may feel confused and find it difficult to make decisions, overwhelmed by a profound perception of helplessness and lack of control. At the psychophysiological level, victim may be startled easily and frequently. At the behavioural level, they may be apathetic and find it difficult to return to everyday life

A victim of kidnapping may experience emotional consequences, which refer to the stabilization of psychological harm, that is, to a permanent incapacity that does not subside with the passage of time, nor with treatment. This constitutes an irreversible alteration of normal psychological functioning, or in legal but conceptually less precise terms, an impairment of mental health [12]. The most common psychological consequences in victims of crimes like kidnapping involve the permanent modification of personality traits (such as emotional dependence, suspiciousness or hostility) that persist for at least two years and lead to a deterioration of interpersonal relationships and performance at work [15]. The transformation of the personality 
may be a chronic state or an irreversible outcome of Post Traumatic Stress Disorder that arises as the consequence of having been the victim of a violent crime [12].

\section{Method}

\subsection{Study Design}

The present work employed the case study design. It was based upon the experiences reported in great detail so that the description captures as much of the unique characteristics of the individual and her situation.

\subsection{Participant/Setting}

A case of kidnap for ransom victim in one of the Niger Delta states was reviewed. The setting was at an industrial clinic owned by a company in the oil and gas sector and located in one of the Niger Delta states in the South-South geopolitical zone of Nigeria.

\subsection{Assessment}

A clinical interview was conducted to examine her mental state and the following psychological instruments were administered:

i. $\quad$ Symptom Distress Checklist - 90 (SCL-90)

ii. $\quad$ State Trait Anxiety Inventory (STAI)

iii. $\quad$ Rosenberg Self Esteem Scale (RSES)

Symptom Distress Checklist-90:Symptom Distress Checklist - 90 (SCL-90) is a 90-item questionnaire developed by Derogatis, Lipman and Covi [16]. SCL-90 is a self-report psychometric instrument. It is designed to evaluate a broad range of psychological problems and symptoms of psychopathology. It is also used in measuring the progress and outcome of psychiatric and psychological treatments or for research purposes. It is scored from 0 (not at all) to 4 (extremely) and the symptoms relate to 10 different dimensions: somatisation, obsessive-compulsive, interpersonal sensitivity, depression, anxiety, hostility, phobic anxiety, paranoid ideation, psychoticism and neuroticism,

State-Trait Anxiety Inventory (STAI) [17]. State-Trait Anxiety Inventory (STAI) is a self-report psychological inventory based on a 4-point Likert scale. The STAI consists of two scales containing 20 items each. The STAI differentiates between the temporary condition of state anxiety and the long-standing quality of trait anxiety so that appropriate treatment can be developed. The total score indicates which type of anxiety is prevalent. Higher scores are positively correlated with higher levels of anxiety. Scores range from 20 to 80, with higher scores correlating with greater anxiety.

Rosenberg Self-Esteem Scale: Rosenberg Self-Esteem Scale [18] is a 10-item self-report measure of global self-esteem. It consists of 10 statements related to overall feelings of self-worth or self-acceptance. The items are answered on a four-point scale, ranging from strongly agree to strongly disagree. Scores range from 10 to 40 . The scale provides a single score of self-esteem with higher scores indicating higher self-esteem.

\subsection{Procedure}

The present exercise was a concerted effort of the management of an oil and gas company to provide quality consultation and kidnap management for the wife of one of their own who had just been released after a week in "captivity" so that she could achieve post-incident support and recovery. In this regard, the authors were consulted for the purpose of carrying out a comprehensive assessment and evaluation with the ultimate goal of providing post-traumatic counselling treatment. The evaluation process took two days and was carried out by the mental health team of psychiatrist and a clinical psychologist who scored and interpreted the results.

\section{Case Report}

D.H. is a 50 -year old mother of one child. She is happily married to a management staff of a company in the oil and gas sector. She is a senior nursing staff working with the state government hospital in one of the towns in Nigeria's Niger Delta region. Her daughter is twenty-three years old undergraduate in another state of the federation. She and her husband are devoted and ordained members of an evangelical church where they hold leadership positions. Although the husband is based in another state, D.H. lives in their personal house.

She was kidnapped from her home as she returned from a church service on a Sunday evening. Two gunmen forcibly kidnapped her in the presence of her own mother who lived in the same town but was visiting that evening. She was bundled into a waiting vehicle and was immediately blindfolded by her captors and taken away. She was driven away along a bushy path. They got to a point where she was brought out of the car, and they embarked upon another journey, first on a motorcycle and later on foot to a hut inside a thick forest. She was subjected to physical abuse - the woman's face was slapped, and she was whipped on the legs several times. The kidnappers would put alcohol into their mouth and later spit the content into her face while she tried hard to convince them that she was just a civil servant. The beatings went on for two days before she was given 
something to eat but she refused to drink or eat anything for the fear that it might be poisoned until the fourth day when she requested for fruit juice. She refused to sleep on the camp bed provided but chose to sleep on a bench. Contact was established with her family through a handset belonging to her mother, which the captors had seized. Each morning she was taken to a different location blindfolded, and brought back to the hut for the night. Meanwhile negotiations went on between the kidnappers and the husband. The kidnappers demanded for the sum of fifty million naira before she could be released. It was negotiated downward and, eventually, she was released after an undisclosed amount of money had been paid as ransom, and that was in the early hours of the seventh day.

\subsection{Results of psychiatric evaluation and psychological assessment}

Mental state examination showed her to be anxious and mildly depressed. There were no features of a psychotic illness. Psychological assessment suggested that she was experiencing bodily pains and discomfort, irresistible thoughts and actions, discomfort in social situation. There was loss of vital energy and interest in usual activities. She was nervous and highly tensed as well as suspicious of movements around her. Lastly, her situation-specific emotion was very high.

\section{Discussion}

The client's overall distress level was very high. This increased psychological distress might have resulted from experiences she had when she was kidnapped. Acierno et al. [14] give some common types of psychological damage a violent victim may experience as adaptive disorder (depressed or anxious mood), post traumatic stress disorder and the imbalance of abnormal personality. More specifically, at the cognitive level, the victim may feel confused and find it difficult to make decisions, overwhelmed by a profound perception of helplessness (being at the mercy of all sorts of dangers) and lack of control (over his or her own life and future); at the psychophysiological level, victims may be startled easily and frequently; at the behavioural level, they may be apathetic and find it difficult to return to everyday life. Esbec [19] notes that the evaluation of psychological harm suffered by victims is important for planning treatment as well as for typifying the harm in criminal terms. Garrido, Stangeland, and Redondo [20] claim that understanding of psychological harm, and the need for its evaluation is not mere intellectual matters. The fundamental purpose is to recognize the psychological condition of the victim, treat it correctly, repair the harm caused, avert revictimisation and avoid the making of new victims.

\section{Conclusion}

This case study highlights the critical importance of mental health assessment as part of a medical evaluation of kidnap-for-ransom victims, after their release. The security forces, employers of labour, family members and health care providers need to be aware of the psychological distress associated with being kidnapped.

\section{References}

[1]. Zannoni, I. E. (2003).Understanding and managing the threat of kidnapping. Zone website, available at http://securitysa.com/article.asp?pkl ArticleID=2443\&pklIssueID=333\&pklCategoryID=88. Accessed July 10, 2012.

[2]. Clutterbuck, R. (2005). Kidnap and ransom, Self-Defense Zone website, available at <http://www.selfdefender.net/ extras/kidnap.htm>, Accessed July 10, 2012.

[3]. Clayton, T. (2004).Dealing with kidnap and ransom. The John Liner Review, 18, p 7.

[4]. Ralph, J. M. (2008). Kidnap, Ransom and Extortion: Protecting your people and your bottom line. Second Quarter.Family Business, Rothstein Kass.

[5]. Hargroves, T. R. (2007). Long march to freedom: the true story of a Colombian kidnapping. p. 318.Texas A \& M University Press

[6]. Sunday Times, July 13, 2004.

[7]. Petersen, W. H. (2008). Countering the threat of kidnapping. Risk Management, 1 - 6

[8]. Mohamed, M. K. N. (2008). Kidnap for Ransom in South East Asian: The Case for a Regional Recording Standard. Asia Criminology, 3, 61-73

[9]. Grose, F. (1811). Dictionary in the Vulgar Tongue http://www.gutenberg.org/cache/epub/5402/pg5402.html Accessed August 12, 2012

[10]. Adibe, J. (2005). http://www.hollerafrica.com/showArticle.php?artId=304\&catId=1 Accessed September 25, 2012

[11]. Kilpatrick, D. J., Saunders, B. E., Amick,-McMullan, A., Best, C. L., Veronen, L. J. \& Jesnick, H. S. (1989). Victim and crime factors associated with the development of crime-related PTSD. Behaviour Therapy, 20, 199 -214

[12]. Echeburua, E., Corral, P., \& Armor, P. J. (2003).Evaluation of Psychological Harm in the Victim of Violent Crime. Psychology in Spain, 7, $10-18$

[13]. Pynoos, R., Sorenson, S., \& Steinberg, A. (1993). Interpersonal violence and traumatic stress reactions. In L. Goldberger \& S. Breznitz (Eds.).Handbook of Stress: Theoretical and Clinical Aspects ( $2^{\text {nd }}$ ed.). New York. Free Press.

[14]. Acierno, R., Kilpatrick, D. G., \& Resnick, H. S. (1999). Posttraumatic stress disorder in adults relative to criminal victimization: Prevalence, risk factors, and co morbidity. In P. A. Saigh \& J. D. Bremner (Eds.). Posttraumatic Stress Disorder: A Comprehensive Text. Needham Heights, M. A. Allyn\& Bacon, Inc.

[15]. Esbec, E. (2000). Evaluation psicologica de la victim.In E. Esbec \& G. Gromez-Jarabo.Psicologiaforense y tratamientojuridico-legal de la discapacidad.Madrid. Edisofer 
[16]. Derogatis, L. R., Lipman, R. S., \& Covi, L. (1973). SCL-90: an outpatient psychiatry rating scale-preliminaryreport. Psychopharmacological Bulletin, 9, 13-28

[17]. Spielberger, C., Gorsuch, R., \& Lushene, R. (1983). STAI Manual for the State-Trait Anxiety Inventory. Palo Alto, CA: Consulting Psychologist Press.

[18]. Rosenberg, M. (1965). Society and The Adolescent Self-Image. Princeton, N.J.: Princeton University Press.

[19]. Esbec, E. (1994). Victimas de delitosviolentos. Victimologia general y forense.In S. Delgado (Ed.). Psiquiatria legal y forense (vol. 2). Madrid Colex.

[20]. Garrido, V., Stangeland, P., \& Redondo, S. (1999). Principios de criminologia. Valencia. Tirant lo blanch. 